\title{
A Study on the Relationship between Information Disclosure and Corporate Governance--Based on Empirical Data of Chinese Listed Companies
}

\section{Yuying Wang}

\author{
Department of Economics and Management, Beihang University, Zhichunlu Street, Haidian District, \\ China \\ yuyingwang1212@yahoo.com \\ *Manying Bai
}

Keywords: information disclosure, internal control, corporate governance

\begin{abstract}
This paper studies the factors that influence the internal control and information disclosure from the perspective of corporate governance. This paper creatively adds corporate governance indicators such as institutional shareholding ratio, the board gender differences, and the board members' overseas background beside some traditional factors such as the size and financial leverage of a company. The results show that the corporate size, ROA, board member government background and institutional shareholding ratio are positively correlated with information disclosure. The financial leverage is negatively correlated with information disclosure. While the independent director ratio, the board gender differences show no significant correlation with information disclosure.
\end{abstract}

\section{Introduction}

From the 2008 financial crisis that spreads around the world to the tragic collapse of China's Letv empire conglomerate, the internal control and information disclosure problem become the wake-up call to all the investors and company directors. Therefore, the internal control regulation of the listed company has been enhanced and a series of draft and measures have been staged in order to regulate the global capital market, raising a new wave of strengthening internal control. Promulgated in 2002, the United States "Sarbanes-oxley" act requires senior manager of the listed company to concern on the effectiveness of internal control self assessment and to hire certified accountant to audit internal control evaluation report. In addition, these steps should adapt to the classification of the type and size of listed companies to strengthen the internal control supervision. Therefore, it is necessary to explore the factors that influence the internal control and information disclosure. Anderson(2011)[1] studied the relationship between manager's professional background, professional experience, gender, educational background and the economic benefits of the company from the personal background of the board of directors. Inspired by his method, this paper select information disclosure index as internal control quality indicators to study how board members' overseas background, government background, independent director ratio and gender heterogeneity influence internal control quality. In terms of academic perspective, exploring the influence of personnel background and gender differences on internal control provides a new direction for corporate governance research. At the same time, it has certain reference value for academic researchers to study the influence factors of enterprise economic effect.

\section{Sample selection and data collection}

The sample period that we examine is between January 12008 and December 312015 from Shenzhen and Shanghai A shares. The data is collected mainly from CSMAR database and Wind financial database. Besides, the missing data is collected from Cninfo website(www.cninfo.com.cn), 
Sina finance, economics (Http//finance.sina.com.cn), and annual reports of listed companies. The sample companies sum up to 3269 and the data set sums up to 26152. After excluding the financial insurance code and comprehensive code, the final data set sums up to 5477. This paper uses STATA software to process data.

\section{Indicators and studying methods}

The following four methods are mainly used to measure information disclosure quality in domestic and foreign empirical studies so far: financial fraud method, earnings management method, KV and bodi internal control information disclosure. Ascioglu Shantarara and John (2005) [2] adopt KV method when studying the relationship of audit fees, information disclosure quality and liquidity since KV to a certain extent reflects the rational analysis of the market investors and has a comparative advantage. This paper adopts KV method that reflects the relationship of information disclosure quality, return rate, and trading volume. The model is as follows:

$$
\begin{gathered}
\ln \left|\frac{\Delta \mathrm{P}_{t}}{p_{t-1}}\right|=\alpha+\beta\left(\mathrm{Vol}_{t}-\mathrm{Vol}_{0}\right)+\varepsilon_{t} \\
\mathrm{KV}=10000 * \beta
\end{gathered}
$$

$\mathrm{P}_{\mathrm{t}}$ is the closing price, Volis the daily trading volume, $\mathrm{Vol}_{\mathrm{t}}$ is the daily trading volume, and $\mathrm{Vol}_{n}$ is the average daily trading volume during the study period.

\begin{tabular}{|c|c|c|}
\hline Indicators & Factors & Contents and computing methods \\
\hline Lnsale $_{i t}$ & Company size & $\begin{array}{l}\text { The natural logarithm of the operating income of the } i \\
\text { company at time. }\end{array}$ \\
\hline Lev $_{\text {it }}$ & Financial leverage & $\begin{array}{l}\text { Financial leverage }=(\text { profit sum }+ \text { financial expense }) \\
\text { total profit. }\end{array}$ \\
\hline $\operatorname{Ind}_{i t}$ & $\begin{array}{l}\text { Proportion of } \\
\text { independent directors }\end{array}$ & $\begin{array}{l}\text { The proportion of independent directors in board in ith } \\
\text { company at } 1 \text { time. }\end{array}$ \\
\hline $\mathrm{ROA}_{\text {it }}$ & Return on assets & (total profit + interest income)/ total assets. \\
\hline BLAU $_{\text {it }}$ & $\begin{array}{l}\text { Director gender } \\
\text { differentiation. }\end{array}$ & $\begin{array}{l}\text { BLAU diversity index: } \mathrm{BLAU}=1-\mathrm{P}_{\mathrm{i}}^{2} \\
\mathrm{P}_{\mathrm{i}} \text { is the proportion of women in the board of directors, } \\
\text { when } P_{i}=0.5 \text {, BLAU reached the maximum (BLAU, } \\
1977)[3] .\end{array}$ \\
\hline$E D U_{i t}$ & $\begin{array}{l}\text { The ratio of member's } \\
\text { overseas background in } \\
\text { board }\end{array}$ & $\begin{array}{l}\text { The proportion of overscas cducation background or } \\
\text { overseas working background. }\end{array}$ \\
\hline$P O L_{i t}$ & $\begin{array}{l}\text { Board member } \\
\text { government background. }\end{array}$ & $\begin{array}{l}\text { Government background can be divided into four } \\
\text { levels: the central government background is graded } 3 \text {, } \\
\text { the province background is graded } 2 \text {, the city and } \\
\text { municipal government background of } 1 \text {, no } \\
\text { government background is graded } 0 \text {, and the sum } \\
\text { numbers added by all the government background level } \\
\text { is divided by the number of directors. }\end{array}$ \\
\hline$I N S_{i t}$ & $\begin{array}{l}\text { The ration of institutional } \\
\text { shareholding }\end{array}$ & The proportion of shares held by institutions. \\
\hline
\end{tabular}

$$
\begin{gathered}
\text { DISC }_{i t}=\alpha+\beta_{1} \text { Lnsale }_{i t}+\beta_{2} \text { Lev }_{i t}+\beta_{3} \text { Ind }_{i t}+\beta_{4} \text { ROA }_{i t}+\beta_{5} B L A U_{i t}+\beta_{6} E D U_{i t} \\
+\beta_{7} \text { POL }_{i t}+\beta_{8} I N S_{i t}+\varepsilon_{i}
\end{gathered}
$$




\section{Regression results}

\begin{tabular}{|r|rrrrr} 
& \multicolumn{7}{c}{ Table 2 Descriptive statistics } \\
Variable & 0bs & Mean & Std. Dev. & Min & Max \\
\hline disc & 5,477 & 6.501668 & .1434015 & 3.689879 & 6.88648 \\
Insale & 5,477 & 21.21944 & 1.397881 & 16.1273 & 25.9991 \\
lev & 5,477 & 2.100643 & 30.03503 & .0041 & 2210.363 \\
ind & 5,477 & .3707246 & .0560761 & .1429 & .7143 \\
roa & 5,477 & .0741285 & 1.477889 & -2.7346 & 108.6448 \\
\hline ins & 5,477 & .3771013 & .2337731 & 0 & .9793 \\
balu & 5,477 & .9609791 & .0633178 & 0 & 1 \\
edu & 5,477 & .064765 & .1113615 & 0 & 1 \\
pol & 5,477 & .5718378 & .4149902 & 0 & 2.6667
\end{tabular}

Table 2 shows the descriptive statistical analysis. The mean value of internal control index is 6.5, which shows a slightly increasing trend compared with last few years. As for the board background characteristics, the proportion of independent directors is 0.37 , which is basically in line with international standards and reaches a high level. However, there is a significant difference between the minimum value 0.1429 and maximum 0.7143 , which means independent directors have obvious differences between different companies. The mean value of board gender is 0.96, indicating the difference is still relatively low. From the actual life we can infer that the majority of the board is still male. The mean value of overseas education background is 0.064 , indicating a low oversea background board ratio. In addition, the average government index of the board directors is 0.521 , indicating that the government background of board members is at a low level.

Table 3 Pearson correlation coefficient test

\begin{tabular}{|c|c|c|c|c|c|c|c|}
\hline & disc & Insale & lev & ind & roa & ins & balu \\
\hline disc & 1.0000 & & & & & & \\
\hline \multirow[t]{2}{*}{ Insale } & 0.3600 & 1.0000 & & & & & \\
\hline & 0.0000 & & & & & & \\
\hline \multirow[t]{2}{*}{ lev } & -0.0105 & 0.0133 & 1.0000 & & & & \\
\hline & 0.4351 & 0.3249 & & & & & \\
\hline \multirow[t]{2}{*}{ ind } & -0.0088 & -0.0114 & 0.0463 & 1.0000 & & & \\
\hline & 0.5173 & 0.3973 & 0.0006 & & & & \\
\hline \multirow[t]{2}{*}{ roa } & 0.0138 & -0.0310 & -0.0016 & 0.0115 & 1.0000 & & \\
\hline & 0.3075 & 0.0220 & 0.9085 & 0.3933 & & & \\
\hline \multirow[t]{2}{*}{ ins } & 0.2396 & 0.3449 & -0.0014 & -0.0420 & 0.0033 & 1.0000 & \\
\hline & 0.0000 & 0.0000 & 0.9196 & 0.0019 & 0.8049 & & \\
\hline \multirow[t]{2}{*}{ balu } & 0.0382 & 0.0999 & -0.0010 & -0.0527 & 0.0066 & 0.0717 & 1.0000 \\
\hline & 0.0047 & 0.0000 & 0.9435 & 0.0001 & 0.6277 & 0.0000 & \\
\hline \multirow[t]{2}{*}{ edu } & 0.0382 & 0.0903 & -0.0099 & 0.0349 & -0.0047 & 0.0615 & -0.0618 \\
\hline & 0.0047 & 0.0000 & 0.4651 & 0.0098 & 0.7292 & 0.0000 & 0.0000 \\
\hline \multirow[t]{2}{*}{ pol } & 0.0611 & 0.0952 & 0.0154 & 0.1089 & -0.0035 & 0.0525 & -0.0186 \\
\hline & 0.0000 & 0.0000 & 0.2556 & 0.0000 & 0.7980 & 0.0001 & 0.1692 \\
\hline
\end{tabular}

Table 3 shows the Pearson correlation coefficient analysis of all samples in order to study the relationship between independent variables and dependent variables. It can be seen from the table that the correlation between institutional investors and management's political background and information disclosure is highly significant. The overseas background proportion of board members is significant at $5 \%$ level, which is positively correlated with the internal control quality, and then preliminarily verifies the feasibility of the hypothesis. 
Table 4 Variance expansion factor VIF test

\begin{tabular}{r|rr} 
Variable & VIF & $1 /$ VIF \\
\hline Insale & 1.16 & 0.862676 \\
ins & 1.14 & 0.876354 \\
pol & 1.02 & 0.977292 \\
balu & 1.02 & 0.980374 \\
ind & 1.02 & 0.980431 \\
edu & 1.02 & 0.984000 \\
lev & 1.00 & 0.997395 \\
roa & 1.00 & 0.998575 \\
\hline Mean VIF & 1.05 &
\end{tabular}

If there is a strong correlation between variables, the regression results are not necessarily convincing. Therefore, the correlation analysis and variance expansion factor analysis are done in this paper to show that the model does not exist in a linear regression. It can be verified by stepwise regression method and VIF of variance expansion factor. In general, if VIF excess 5, the multiple co-linearity may exist. Table 3 shows the correlation coefficients between the variables. It can be seen from the table that the correlation coefficient between each variable is less than 5 , so it is possible to judge that the model does not exist an obvious multi-collinear. It can also be seen from the table that the correlation of several other variables is not very high, so it can exclude the effects of multiple co-linearity.

Table 5 Sample regression

\begin{tabular}{|c|c|c|c|c|c|c|}
\hline Source & SS & df & MS & Number of obs & $=$ & 5,477 \\
\hline Model & 16.4540569 & 8 & 2.05675711 & Prob $>\mathrm{F}$ & $=$ & .00 \\
\hline Residual & 96.1544175 & 5,468 & .017584934 & R-squared & $=$ & 0.146 \\
\hline Total & 112.608474 & 5,476 & .020564002 & Root MSE & $=$ & .132 \\
\hline
\end{tabular}

\begin{tabular}{r|rrrrrr}
\hline disc & Coef. & Std. Err. & $\mathrm{t}$ & $\mathrm{P}>|\mathrm{t}|$ & [95\% Conf. & Interval] \\
\hline Insale & .032198 & .0013802 & 23.33 & 0.000 & .0294922 & .0349038 \\
lev & -.0000706 & .0000597 & -1.18 & 0.237 & -.0001877 & .0000465 \\
ind & -.0054879 & .032274 & -0.17 & 0.865 & -.0687577 & .057782 \\
roa & .0022492 & .0012134 & 1.85 & 0.064 & -.0001296 & .004628 \\
ins & .0797289 & .0081885 & 9.74 & 0.000 & .0636762 & .0957817 \\
balu & -.0050328 & .0285836 & -0.18 & 0.860 & -.0610681 & .0510025 \\
edu & .0013364 & .0162221 & 0.08 & 0.934 & -.0304653 & .0331381 \\
pol & .008589 & .0043681 & 1.97 & 0.049 & .0000258 & .0171521 \\
cons & $\mathbf{5 . 7 9 0 2 3 2}$ & .0398197 & 145.41 & 0.000 & 5.71217 & 5.868295
\end{tabular}

Table 5 shows the regression results of variables. The correlation coefficient between information disclosure and company size is 0.0323 , indicating that there is a positive correlation. And it is significantly effective since the $\mathrm{P}$ value is close to 0 . The larger the size of the company, the higher quality of internal control information disclosure. There are many existing explanations: the compiling information cost of big companies is relatively low, as a result, the loss of adverse competition resulting from information disclosure is low (Meek et al, 1995) [4]; From the perspective of releasing information cost, the cost of small companies is relatively high, since the media is more willing to publish the information of big companies (Lang \& Lundholm, 1993) [5]. The correlation coefficient of financial leverage and information disclosure is negative, indicating a negative correlation. But the $\mathrm{P}$ value is 0.237 , which is not very significant. The correlation coefficient between information disclosure and independent directors is negative, but the significance test is very low. However, some theory holds that the larger proportion of independent directors, the more effective it is to supervise the board of directors, so that companies tend to disclose more voluntarily. Independent directors can be seen as a tool to monitor managers' behavior, thus higher proportion of independent directors on the board can motivate the will of voluntary disclosure. But there is no unified conclusion among scholars: Wong and $\mathrm{Ho}(2014)[6]$ claim that the proportion of independent 
directors is positively correlated with the will of voluntary disclosure of listed companies, but such correlation is not significant. While the research of Mark and Eng(2002) [7] shows that, with the increase of independent directors in the board, the level of voluntary disclosure is gradually declining. Domestic scholars Zhong Weiqiang et al. (2006) [8] find that the existence of independent directors did not have a significant positive effect on the level of voluntary disclosure of listed companies in China. According to the Zhong Tianli(2004) [9] , the proportion of independent directors is positively correlated with the degree of voluntary information disclosure.

The correlation coefficient of return on assets and the information disclosure is 0.22 and the significance level $\mathrm{P}$ is 0.64 , indicating a weak positive correlation. The correlation coefficient of gender differentiation and information disclosure is -0.05 , which means there is no significant correlation between them. There is no obvious correlation between overseas study background and information disclosure. The correlation between government background and information disclosure is 0.086 , and the significance value $\mathrm{P}$ is 0.049 . It can be said that there is a positive correlation with 95\% confidence. From the current situation in China, the government act as a role of supervision enterprises and government departments concern more on enterprise risk and market risk. Compared with performance, the risk has greater impact on government decision. The correlation coefficient of institutional investors ratio and information disclosure is 0.797 , which is very significant, indicating that institutional ownership and information disclosure exist a very strong positive correlation.

\section{Conclusions}

This paper select data of listed companies from Shenzhen and Shanghai A shares and creatively adds corporate governance indicators such as institutional shareholding ratio, the board gender differences, and the board members' overseas background beside some traditional factors such as the size and financial leverage of a company. The results show that the corporate size, ROA, board member government background and institution shareholding ratio are positively correlated with information disclosure. The financial leverage is negatively correlated with information disclosure. While the independent ratio, the board gender differences show no significant correlation with information disclosure.

\section{Acknowledgments}

This work was supported by the National Natural Science Foundation of China (Grant No. 71571007, 71330014).

\section{References}

[1]Eng, Anderson. Corporate governance and voluntary disclosure. Journal of Accountancy. (2011)

[2]Ascioglu Shantarara, John. The Economic Theory of Agency: The Principal's Problem. The American Economist. (2005)

[3]Fama E, French K. Industry costs of equity. The Journal of Finance. (1977)

[4]Meek J, M. Rodriguez. Corporate governance and disclosure quality. Accounting and Business. (1995)

[5]Lang \& Lundholm. Additional evidence on the association between the investment opportunity set and corporate financing, dividend, and compensation policies. Journal of Accountancy. (1993)

[6]Yinghong Wong, Ho Zhang. Cost to Comply with SOX. Auditing A Journal of Practice Theory. (2014)

[7]Mark Gietzman, Miles Trombetta. Disclosure Interactions: Accounting Policy Choice and Voluntary DisclosureEffects on the Cost of Capital. Accounting and Business. (2002) 
[8]Zhong Weiqiang. The Investment Opportunity Set and Corporate Financing, Dividend and Compensation Policies. The Journal of Finance. (2006)

[9]Zhong Tianli. A Strategic Posture Toward Corporate Social Responsibility. California Management Review. (2004) 